\title{
Detection of Microbial Contamination in Commercial Berries
}

\author{
Kyu-Bong Cho ${ }^{\dagger}$ \\ Department of Biomedical Laboratory Science, Shinhan University, Gyeonggi 11644, Korea
}

\begin{abstract}
This study was performed to assess microbial contamination of Aronia melanocarpa, blueberry, raspberry, and cranberry sold in several markets. We investigated total aerobic bacteria and detected foodborne bacteria by multiplex PCR from Aronia melanocarpa, blueberry, raspberry, and cranberry. Total aerobic bacteria of each sample showed mean 3.54 log CFU/g for Aronia melanocarpa, mean $1.90 \mathrm{log}$ CFU/g for blueberry, and mean $1.40 \mathrm{log}$ CFU/g for raspberry, but not detected in cranberry. Specially, Aronia melanocarpa contained high total aerobic bacteria contamination among various berries and contamination level reached $4.17 \log \mathrm{CFU} / \mathrm{g}$ in sample 5. To evaluate the effect of distribution conditions, we also investigated total aerobic bacteria of various berries. Total aerobic bacteria showed mean 2.89 log CFU/g for berries in refrigerated distribution and $1.40 \mathrm{log} \mathrm{CFU} / \mathrm{g}$ in frozen distribution, but not in dry distribution. For assessment of foodborne bacteria contamination, we conducted PCR with multiplex primers of E. coli O157, S. aureus, B. cereus, V. parahaemolyticus, L. monocytogenes, Y. enterocolitica, Salmonella spp., Shigella spp. Among these foodborne bacteria, B. cereus was amplified in Aronia melanocarpa in sample 4 and blueberry in sample 1, 2, 3, and 5. The result of quantitative analysis of B. cereus contamination showed $4.08 \log$ CFU/g of Aronia melanocarpa in sample 4 and higher contamination rate $4.07 \log \mathrm{CFU} / \mathrm{g}$ of blueberry in sample 3 . These results suggest that strict food safety control in harvest and distribution of various berries is necessary to prevent foodborne disease and improve microbiological safety.
\end{abstract}

Key Words: Berries, Total aerobic bacteria, Foodborne bacteria, PCR, B. cereus

\section{서 론}

최근 의학의 발달로 고령화시대가 도래함에 따라 다양 한 식물성 기능식품의 효능에 대한 활발한 연구가 진행되 고 있다. 특히 베리류에 들어있는 항산화물질이 세포 내 자유라디칼을 소거하여 노화를 지연시켜주고 스트레스로 인한 질병에 효과가 있다는 효능이 알려지기 시작하면서 전 세계적으로 베리류의 소비가 증가하고 있다(Lee and $\mathrm{Bae}, 2011 ; \mathrm{FAO}, 2014)$. 최근에는 국내에서도 베리류의 재 배면적이 크게 증가되고 있으며 향후 생산량 및 소비량이 크게 증가할 것으로 예상되고 있다(Kim et al., 2013). 반면
에 베리류의 생산과 소비가 증가하고 있지만, 가공 및 유 통과정에서 위생과 안전관리가 제대로 이루어지지 않는 다면 식중독 등 위해가 발생할 가능성이 매우 커지고 있 는 실정이다. 특히 베리류는 토양에서 자라는 식물로 수 확과정에서 토양과 관계용수와의 접촉, 작업자의 비위생 적인 취급 등으로 인하여 미생물에 오염될 가능성이 높다 (Pangloli and Hung, 2013). 실제로 토양에서 성장하는 다양 한 견과 종실류가 B. cereus에 심각하게 오염되어 있음이 국내에서 보고된 바 있다(Hong, 2016). 그러므로 베리류의 안전성을 확보하기 위해서는 생산, 수확 후 관리 및 유통 단계에서 베리류에 잔류할 수 있는 미생물학적 위해요소 를 적절하게 관리하는 것이 필요하다(Lee et al., 2009).

* Received: November 7, 2017 / Revised: November 23, 2017 / Accepted: November 23, 2017

${ }^{\dagger}$ Corresponding author: Kyu-Bong Cho. Department of Biomedical Laboratory Science, Shinhan University, Gyeongg 11644, Korea. Tel: +82-31-870-3712, Fax:+82-31-870-3719, e-mail: kbcho@shinhan.ac.kr

(C) The Korean Society for Biomedical Laboratory Sciences. All rights reserved.

(c) This is an Open Access article distributed under the terms of the Creative Commons Attribution Non-Commercial License (http://creativecommons.org/licenses/by-nc/3.0/) which permits unrestricted non-commercial use, distribution, and reproduction in any medium, provided the original work is properly cited. 
식품으로 인한 위해를 방지하고 안전성을 확보하기 위 하여 식품 원료의 생산에서부터 유통단계까지 많은 노력 들이 필요하며 국가 차원에서 철저한 식중독 관리가 이루 어지고 있음에도 불구하고 식품의 섭취로 인한 식중독 환 자와 발생건수는 줄어들지 않고 있다(식품안전정보포털). 특히 미국에서는 2013년까지 라즈베리(raspberrry)의 섭취 가 원인이 되어 여러 번의 대형 식중독이 발생한 사례가 보고되었다(Xu and $\mathrm{Wu}, 2016)$. 이는 소비자들이 베리류를 구매하여 별도의 열 처리나 세척없이 그대로 섭취하거나 동결 후 냉동 상태로 이용하기 때문에 오염된 미생물에 의한 식중독 유발 가능성이 더욱 높기 때문이다(Oms-Oliu et al., 2010). 이러한 베리류의 미생물 오염을 낮추기 위한 방법의 일환으로 이산화염소 등 화학적 살균제들 및 염소 계 살균제를 대체할 수 있는 세척살균에 대한 연구가 활 발하게 진행되고 있다(Keskinen et al., 2009; Vaid, 2010). 하 지만 베리류의 특성이 반영된 위생 상태에 대한 조사가 잘 이루어지지 않고 있으며 구체적인 위생기준의 마련 또 한 시급한 상태이다.

시중에 유통 및 판매되고 있는 베리류는 가열과정 없이 그대로 섭취하는 특성으로 인하여 식중독의 발생 위험이 다른 식품들에 비하여 매우 높을 것으로 예상된다. 따라 서 본 연구에서는 시중에 유통되고 있는 베리류에 대한 미생물학적 오염도를 파악하여 위생실태를 조사하고자 실 시하였다.

\section{재료 및 방법}

\section{베리류 구입 및 검체액 제조}

본 연구대상 시료는 2017년 6월부터 서울북부 및 경기 북부 지역에 소재하는 4곳의 대형마트 매장에서 4종류의 베리류 총 18 개의 시료를 구입하여 실험에 사용하였다. 구 입한 베리류는 아로니아(Aronia melanocarpa) 5 개 시료, 블 루베리(blueberry) 5 개 시료, 랩스베리(raspberry) 4개 시료, 크랜베리(cranberry) 4개 시료이다. 구입한 베리류 시료를 멸균백에 넣고 시료와 멸균생리식염수를 $1: 10(\mathrm{w} / \mathrm{v})$ 의 비 율로 하여 bag-mixer (Interscience, HG-92G, USA)로 1분간 균질화하였다.

\section{일반세균 정량분석}

일반세균은 균질화된 희석용액 $1 \mathrm{ml}$ 를 일반세균수 측정 건조배지(aerobic count plate, $3 \mathrm{M}, \mathrm{USA}$ )에 triplicate로 분주 하여 $35^{\circ} \mathrm{C}$ 에서 24 48시간 동안 배양한 후 붉은 집락수를
계산하였으며 평균 집락수에 희석배수를 곱하여 최종균수 를 산출하였다.

\section{Multiplex PCR에 의한 식중독균 조사}

식중독균에 대한 검출은 식품의약품안전처의 식중독 원 인조사 시험법 가이드라인을 준수하여 multiplex PCR을 수행하였다. Listeria monocytogenes는 시료 $25 \mathrm{~g}$ 과 Listeria enrichment broth (LEB) $225 \mathrm{ml}$ 를 멸균백에 넣어 bag-mixer 를 이용하여 $\mathrm{mix}$ 한 후 $35^{\circ} \mathrm{C}$ 에서 48 시간 배양하였으며 기 타 나머지 식중독 원인균은 tripticase soy broth (TSB) 배지 를 이용하여 동일한 방법으로 $\mathrm{mix}$ 한 후 $35^{\circ} \mathrm{C}$ 에서 24 시간 배양하였다. $\mathrm{LEB}$ 와 $\mathrm{TSB}$ 에서 증균된 각 시료의 $\mathrm{DNA}$ 는 Power prep ${ }^{\mathrm{TM}}$ DNA extraction kit (Kogenbiotech, Korea)를 이 용하여 제조사가 제시하는 방법에 따라 추출하였다. 간단 히 요약하면 증균액 $1 \mathrm{ml}$ 에 $400 \mu \mathrm{l}$ 의 lysis buffer $\mathrm{A}$ 와 $40 \mu \mathrm{l}$ 의 lysis buffer $\mathrm{B}, 10 \mu \mathrm{l}$ 의 proteinase $\mathrm{K}$ 와 RNase $\mathrm{A}$ 를 넣고 $65^{\circ} \mathrm{C}$ water bath에서 1시간 동안 반응시킨 후 binding buffer $400 \mu \mathrm{l}$ 를 첨가하였다. Spin column과 원심분리를 이용하여 시료의 DNA를 침전시킨 후, washing buffer $600 \mu \mathrm{l}$ 로 세척 한 다음, elution buffer $100 \mu \mathrm{l}$ 에 녹여 $8,000 \mathrm{rpm}$ 으로 3 분 원심분리하여 DNA를 추출하여 multiplex PCR에 사용하 였다.

Multiplex PCR kit는 E. coli O157, Staphylococcus aureus, Bacillus cereus, Vibrio parahaemolyticus, Listeria monocytogenes, Yersinia enterocolitica, Salmonella spp., Shigella spp. 등 총 8종 의 식중독 원인균을 검출하기 위하여 제조된 powerchek ${ }^{\mathrm{TM}}$ multiplex pathogen detection kit (Kogenbiotech, Korea)를 이 용하여 $\mathrm{PCR}$ 을 수행하여 각각의 식중독 원인균에 대한 특 이 유전자를 증폭하였다. Multiplex primers의 각 세균별 대상유전자와 증폭산물의 DNA의 크기는 Table 1 과 같다. Polymerase chain reaction (PCR)을 수행하기 위하여, 총 반 응액이 $20 \mu \mathrm{l}$ 가 되도록 primer mix $4 \mu \mathrm{l}, 5 \times$ reaction buffer $4 \mu \mathrm{l}, \mathrm{Taq}$ DNA polymerase $0.5 \mu \mathrm{l}$, template DNA와 distilled water를 첨가하여 $95^{\circ} \mathrm{C}$ 에서 10 분 동안 반응시킨 후 $95^{\circ} \mathrm{C}$ 에서 30 초, $60^{\circ} \mathrm{C}$ 에서 30 초, $72^{\circ} \mathrm{C}$ 에서 30 초 반응 조건으로 35 cycle을 증폭하였다. PCR 증폭에는 $\mathrm{MJ}$ research PCR system을 이용하였다. 이렇게 얻어진 PCR 증폭산물은 $2 \%$ agarose gel에서 전기영동 후 ethidium bromide $(\mathrm{EtBr})$ 로 염색 하여 확인하였다.

\section{B. cereus 정량검사}

$\mathrm{PCR}$ 을 통하여 검출된 주요 식중독균인 B. cereus에 대하 
Table 1. PCR amplicon size in multiplex PCR

\begin{tabular}{clcc}
\hline \hline \multicolumn{1}{c}{ Control } & \multicolumn{1}{c}{ Pathogen } & Target gene & Amplicon size (bp) \\
\hline \multirow{2}{*}{ Control DNA 1 } & Salmonella spp. & invA & 675 \\
& Listeria monocytogenes & prfA & 450 \\
& Bacillus cereus & groEL & 303 \\
& E. coli O157 & VT2 & 208 \\
\hline \multirow{3}{*}{ Yersinia enterocolitica } & inv & 562 \\
& Vibrio paraheamolyticus & toxR & 375 \\
& Staphylococcus aureus & femA & 264 \\
& Shigella spp. & ipaH & 141 \\
\hline
\end{tabular}

여 각 시료별로 정량검사를 실시하였다. 검출된 시료와 멸 균생리식염수를 $1: 10(\mathrm{w} / \mathrm{v})$ 의 비율로 하여 bag-mixer에 넣 고 1 분간 균질화 한 후에 10 배로 계단 희석하였다. 희석 액 $0.2 \mathrm{ml}$ 을 mannitol egg yolk polymicin agar (MYP agar; $\mathrm{Difco}, \mathrm{USA}$ )에 도말하여 $30^{\circ} \mathrm{C}$ 에서 24 시간 배양한 후 생성 된 집락수를 계수하였다.

\section{결 과}

\section{일반세균수 오염도 분석}

베리류의 일반세균수 오염도를 분석하기 위하여 대형마 트 4곳에서 아로니아, 블루베리, 랩스베리, 크랜베리 18 개 시료를 구입하여 시료를 증류수에 단계별로 희석한 후 일 반세균수 측정 건조필름배지에 접종하고 배양하여 집락수 를 측정하였다. 아로니아는 3 개의 시료에서 일반세균이 검출되었고 블루베리는 2 개의 시료에서 일반세균이 검출 되었으며 랩스베리 역시 2개의 시료에서 검출되었다. 크 랜베리는 구입한 모든 시료에서 일반세균이 검출되지 않 았다(Table 2). 아로니아는 시료 5에서 $4.17 \log \mathrm{CFU} / \mathrm{g}$ 으로 가장 높은 오염을 보였으며 평균 $3.54 \log \mathrm{CFU} / \mathrm{g}$ 를 나타냈 다. 블루베리는 시료 2 와 시료 5 에서 일반세균이 검출되 었으며 평균 $1.90 \log \mathrm{CFU} / \mathrm{g}$ 를 나타냈다. 랩스베리는 시료 1 과 시료 4에서 검출되었고 평균 $1.40 \log \mathrm{CFU} / \mathrm{g}$ 를 나타냈 다. 그러므로 시중에 유통되는 베리류 중에서 일반세균 오염이 가장 심한 것은 아로니아로 나타났다.

구입한 베리류는 건조, 냉장, 냉동 상태로 구분하여 시 중에서 유통되고 있어 베리류의 유통 조건에 따른 일반세 균수 오염도를 분석하였다. 그 결과, 건조 상태로 유통되 는 베리류에서는 일반세균이 검출되지 않았으며 냉장 상 태로 유통되는 베리류는 평균 $2.89 \log \mathrm{CFU} / \mathrm{g}$ 가 검출되었
Table 2. Number of total aerobic bacteria in berries

\begin{tabular}{lccc}
\hline \hline \multirow{2}{*}{ Type of berries } & Samples & \multicolumn{2}{c}{$\begin{array}{c}\text { Total aerobic bacteria } \\
\text { (log CFU/g) }\end{array}$} \\
\cline { 2 - 4 } Aronia & & Each & Mean \pm SD \\
melanocarpa & 2 & 3.73 & \\
& 3 & ND & \\
& 4 & 2.73 & \\
\hline \multirow{3}{*}{ Blueberry } & 5 & 4.17 & \\
& 1 & ND & \\
& 2 & 2.0 & \\
\hline \multirow{4}{*}{ Raspberry } & 3 & ND & $1.90 \pm 0.14$ \\
& 4 & ND & \\
& 5 & 1.90 & \\
\hline Cranberry & 1 & 1.30 & \\
& 2 & ND & $1.40 \pm 0.14$ \\
& 3 & ND & \\
\hline & 4 & 1.50 & ND \\
& 1 & ND & \\
& 2 & ND & \\
& 3 & ND & \\
& 4 & ND & \\
\hline
\end{tabular}

Abbreviations: CFU, colony forming unit; SD, standard deviation; ND, not detected.

다. 또한 냉동 상태로 유통되는 베리류는 평균 $1.40 \mathrm{log}$ $\mathrm{CFU} / \mathrm{g}$ 의 일반세균이 검출되었다(Table 3$)$.

\section{Multiplex PCR을 이용한 식중독균 조사}

베리류의 식중독균 오염을 분석하기 위하여 E. coli $\mathrm{O} 157$, S. aureus, B. cereus, V. parahaemolyticus, L. monocytogenes, $Y$. 
Table 3. Number of total aerobic bacteria according to distribution conditions of berries

\begin{tabular}{lc}
\hline \hline \multicolumn{1}{c}{ Distributions } & $\begin{array}{c}\text { Total aerobic bacteria } \\
(\log \text { CFU/g) }(\text { Mean } \pm \text { SD })\end{array}$ \\
\hline Refrigerated distribution & $2.89 \pm 1.04$ \\
Frozen distribution & $1.40 \pm 0.14$ \\
Dry distribution & $\mathrm{ND}$ \\
\hline
\end{tabular}

Abbreviations: CFU, colony forming unit; $\mathrm{SD}$, standard deviation; $\mathrm{ND}$, not detected.

Table 4. Number of B. cereus detected from various berries

\begin{tabular}{lcc}
\hline \hline Type of berries & Samples & B. cereus $(\log$ CFU/g) \\
\hline Aronia melanocarpa & 4 & 4.08 \\
\hline \multirow{3}{*}{ Blueberry } & 1 & 3.68 \\
& 2 & 3.73 \\
& 3 & 4.07 \\
& 5 & 3.67 \\
\hline
\end{tabular}

Abbreviations: CFU, colony forming unit

enterocolitica, Salmonella spp., Shigella spp. 등 8종의 주요 식중독균 multiplex primes를 이용하여 polymerase chain reaction $(\mathrm{PCR})$ 을 수행하였다. 각 시료를 식중독균 증식배 지에 희석하여 배양하고 증식한 세균의 DNA를 추출하여 $\mathrm{PCR}$ 에 이용하였다. 4 개의 블루베리 시료와 한 개의 아로 니아 시료에서 B. cereus가 검출되었으며 랩스베리와 크랜 베리에서는 주요 식중독균의 DNA가 검출되지 않았다(Fig. 1). $\mathrm{PCR}$ 결과 B. cereus 유전자 증폭 양상이 시료에 따라 다소 차이가 있는 것을 알 수 있었다. 유전자 증폭산물의 양이 시료에 따라 차이가 있었으며, 가장 증폭 양이 작은 것은 블루베리의 시료 1 로 나타났고, 가장 증폭 양이 많은 것은 블루베리의 시료 3 으로 나타났다.

\section{B. cereus 오염도 분석}

베리류에서 식중독을 유발하는 원인균의 분포를 확인하 기 위하여 $\mathrm{PCR}$ 을 수행한 결과 B. cereus가 검출되었으며 검출된 베리류에서 B. cereus의 오염 정도를 확인하기 위 하여 정량실험을 수행하였다. 아로니아의 경우 시료 4에 서 $4.08 \log \mathrm{CFU} / \mathrm{g}$ 가 검출되었으며 블루베리의 경우 시료 1 에서 $3.68 \log \mathrm{CFU} / \mathrm{g}$, 시료 2에서 $3.73 \log \mathrm{CFU} / \mathrm{g}$, 시료 3에서 $4.07 \log \mathrm{CFU} / \mathrm{g}$, 그리고 시료 5에서 $3.67 \log \mathrm{CFU} / \mathrm{g}$ 가 검출되었다(Table 4). 블루베리 시료들에서 가장 B. cereus
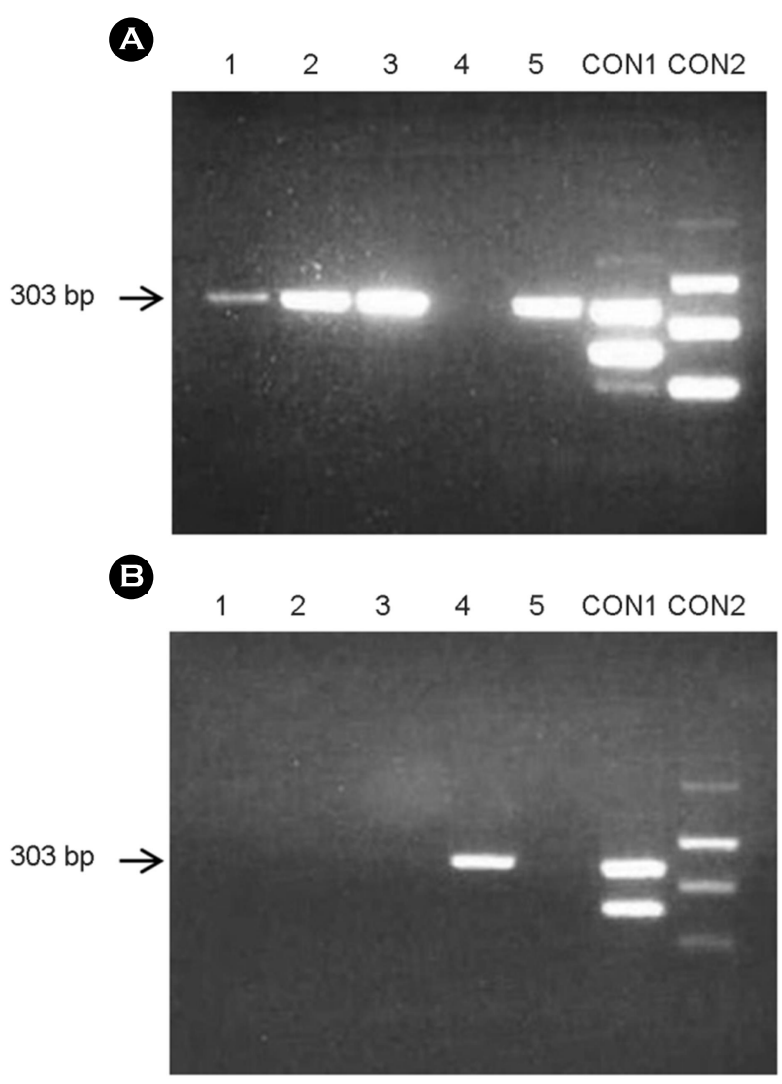

Fig. 1. Detection of foodborne bacteria by PCR using multiplex pathogen detection primers from Blueberry (A) and Aronia melanocarpa (B). 1: sample 1, 2: sample 2, 3: sample 3, 4: sample 4, CON1: control DNA 1, CON2: control DNA2.

의 오염이 심한 것은 시료 3으로 나타났다. 이러한 결과 는 PCR 수행 시 가장 많은 유전자가 증폭된 결과와 일치 하는 것을 알 수 있었다. 또한 모두 냉장 상태로 유통되고 있는 베리류에서만 B. cereus가 검출되었고 건조 및 냉동 유통에서는 식중독균이 검출되지 않았다.

\section{고 찰}

본 연구에서는 건강을 유지하고 질병의 예방에 필요한 다양한 생리활성물질을 함유하고 있는 것으로 알려지면서 최근 소비량이 급증하고 있는 베리류에 대한 미생물학적 안전성을 확인하기 위하여, 시중에 유통되고 있는 다양한 종류의 베리류에서 미생물 오염을 분석하고자 수행하였다. 연구 결과, 시중에 유통되고 있는 베리류에서 일반세균이 검출되었으며 가장 오염이 심한 것은 아로니아로 나타났 다. 또한 건조, 냉장, 냉동 유통 조건에 따른 일반세균 오 
염도를 비교한 결과 냉장 유통의 경우가 일반세균의 오염 이 가장 심하고 그 다음이 냉동 유통으로 나타났다. 건조 상태로 유통되는 베리류에서 일반세균이 검출되지 않은 것 은 수분활성도가 낮아서 미생물이 증식하기에 적합하지 못한 환경 때문이라 생각된다. 냉장 상태로 유통되는 베 리류는 다른 유통 조건보다 미생물이 증식하기에 비교적 적합한 온도로 인하여 가장 높은 오염도를 보였을 것으로 생각된다. 하지만 국내에서 베리류를 경작하는 토양에서 일반세균을 비롯한 다양한 세균들이 뿌리와 함께 증식하 고 있다는 것이 보고된 바 있으며(Ahn et al., 2010) 토양으 로부터 유래하는 것 외에도 작업자의 비위생적인 취급, 안전하지 못한 작업환경, 유통과정에서의 오염 등 다양한 원인들에서 기인하는 것으로 알려졌다. 그러므로 수확 후 베리류에 미생물의 오염을 방지하기 위한 더욱 철저한 위 생관리가 이루어져야 할 것으로 생각되며, 이를 위해 현 재 베리류의 미생물학적 품질향상을 위한 세척시스템 개 발 및 저장 기간 동안의 미생물학적 안전성을 확보 등을 위한 연구들이 활발히 이루어지고 있는 실정이다(Kim et al., 2010; Chun et al., 2013).

베리류에서 다양한 종류의 식중독 원인균의 오염 정도 를 분석하기 위하여 multiplex PCR을 이용하여 식중독 원 인균의 유전자를 증폭하였다. 그 결과, 아로니아와 블루베 리에서 B. cereus 가 검출되었으며, E. coli O157, S. aureus, B. cereus, V. parahaemolyticus, L. monocytogenes, Y. enterocolitica, Salmonella spp., Shigella spp.는 모든 베리류에서 검출되지 않았다. 또한 B. cereus의 오염 정도가 시중에 유통되고 있 는 판매 장소에 따라 차이가 있는 것을 알 수 있었다. 어 떤 장소의 시료에서는 블루베리와 아로니아에서 모두 $B$. cereus 가 검출되었으며 어떤 장소의 시료에서는 모든 식 중독 원인균이 검출되지 않았다. 그러므로 베리류의 유통 및 판매 장소에 따라 일반세균 및 식중독균의 오염도 또 한 다르다는 것을 알 수 있었으며, 유통과정 중의 위생관 리에도 차이가 있는 것으로 사료된다. B. cereus는 주요 식 중독 원인균으로 구토와 설사 증상을 나타내고, 포자와 독소를 형성하는 감염성 및 독소형 식중독을 유발하는 것 으로 알려져 있으며 토양을 비롯하여 자연계에 널리 분포 하고 있어 식품에 오염될 가능성이 높고 식품에 소량만 오염되어도 식중독을 유발할 수 있어 국가에서 식품 유형 별에 따라 기준을 정하여 관리하고 있다(Ceuppens et al., 2013).

다양한 베리류에 대한 미생물의 오염은 재배환경 및 수 확 중의 거름, 관계용수, 유통단계에서 비위생적인 취급
등이 원인으로 조사되고 있으며(Lee and Eom, 2016). 특히 B. cereus 는 자연계에 주로 분포하는 식중독 원인균으로 토 양과 밀접하게 접촉하여 재배하는 농산물에서 오염도가 높고 식중독 발생률도 많은 것으로 보고되었다(Hong et al., 2012). 또 다른 원인으로 작업자의 개인위생 불량 등으로 오염될 가능성이 높을 것으로 생각된다(Kim et al., 2011; Chang, 2016). 베리류의 경우 크기가 작은 과일류이나 표 면적이 넓고 과피가 연약하여 물리적인 손상이나 조직의 연화 등으로 쉽게 물러지고 미생물 오염에 취약하기 때문 에 수확하고 포장하는 단계에서 비위생적인 작업자의 손 을 통하여 교차오염이 일어날 확률이 높을 것으로 생각된 다. 최근에는 식품의 안전성을 확보하기 위하여 신선편의 식품에서 미생물 생장 가능성을 예측하는 분야의 연구가 활발하게 이루어지고 있다. 따라서 식품의 저장온도와 포 장 방법, 세척 및 살균 처리 등 다양한 조건에서 시간의 경과에 따른 미생물의 수를 측정한 결과를 바탕으로 미생 물 오염 가능성을 예측하는 수학 모델들이 개발되고 있으 나, 베리류의 경우 세척 및 저장과정에서 미생물 예측에 대한 연구는 매우 부족한 상태이다. 최근 질병의 예방 및 건강에 대한 관심이 높아지면서 다양한 효능을 나타내는 생리활성물질들을 포함하고 있는 베리류의 소비량이 급증 하고 있는 상황이나 베리류는 가열하지 않고 섭취하는 특 성으로 인하여 식중독 유발의 심각성이 매우 높게 나타나 고 있다. 그러므로 베리류로 인한 위해(harm)를 예방하고 식품의 안전성을 확보하기 위하여 베리류의 생산 및 유통 단계에서 체계적이고 과학적인 위생관리와 이를 위한 연 구가 필요할 것으로 생각된다.

\section{ACKNOWLEDGEMENTS}

This work was supported by the Shinhan University Research Fund, 2017.

\section{CONFLICT OF INTEREST}

The author has no conflict of interest.

\section{REFERENCES}

Ahn BK, Lee JH, Kim KC, Choi DC, Lee JH, Han SS. Investigation of relationships between soil physic-chemical properties and topography in Jeonbuk upland fields. Korean Journal of Soil Science and Fertilizer. 2010. 43: 268-274.

Ceuppens S, BoonN, Uyrrendaele M. Diversity of Bacillus cereus 
group strains if reflected in their broad range of pathogenicity and diverse ecological lifestyles. FEMS Microbiology Ecology. 2013. 84: 433-450.

Chong MS. Bacterial contamination in disposable wet wipes from general restaurants. Korean Journal of Clinical Laboratory Science. 2016. 48: 237-241.

Chun HH, Park SH, Choi SR, Song KB, Park SJ, Lee SH. Development of washing system for improving microbiological quality of blueberry after Postharvest. Journal of the Korean Society of Food Science and Nutrition. 2013. 42: 1886-1891.

Food and Agriculture Organization (FAO). Food and agricultural organization statistics database (FAOSTAT). 2014.

Hong CK, Seo YH, Choi JM, Hwang IS, Kim MS. Microbial quality of fresh vegetables and fruits in Seoul, Korea. Journal of Food Hygiene and Safety. 2012. 27: 24-27.

Hong SH. Investigation of microbial contamination of nuts and seeds. Journal of the Korea Entertainment Industry Association. 2016. 10: 397-403.

Keskinen LA, Burke A, Annous BA. Efficacy of chlorine, acidic electrolyzed water and aqueous chlorine dioxide solutions to decontaminate Escherichia coli O157:H7 from lettuce leaves. International Journal of Food Microbiology. 2009. 132: 134 -140 .

Kim JG, Park JY, Kim JS. A comparison of microbial load on bare and gloved hands among food handlers. Journal of Environ- mental Health Sciences. 2011. 37: 298-305.

Kim JY, Kim HJ, Lim GO, Jang SA, Song KB. The effects of aqueous chlorine dioxide or fumaric acid treatment combined with UV-C on postharvest quality of 'Maehyang' strawberries. Postharvest Biology and Technology. 2010. 56: 254-256.

Kim SJ, Park KS, Park SJ, Kwon YH. Current status of blueberry culture in Korea. Korean Journal of Horticultural Science and
Technology. 2013. 31: 139-139.

Lee EJ, Bae JH. Study on the alleviation of an alcohol induced hangover and the antioxidant activity by mulberry fruit. The Korean Journal of Food and Nutrition. 2011. 24: 204-209.

Lee HW, Yoon YH, Seo EK, Kim KY, Shim WB, Kil JK, Jung DH. Microbial hazard analysis for agricultural products processing center of tomato and recommendations to introduce good agricultural practices (GAP) system. Korean Journal of Food Science and Technology. 2009. 41: 210-214.

Lee SY, Eom YB. Analysis of microbial composition associated with freshwater and seawater. Biomedical Science Letters 2016. 22: 150-159.

Oms-Oliu G, Rojas-Grau MA, Gonzalez LA, Varela P, SolivaFortuny R, Hernando MIH. Recent approaches using chemical treatments to preserve quality of fresh-cut fruit: A review. Postharvest Biology and Technology. 2010. 57: 139-148.

Pangloli P, Hung YC. Reducing microbiological safety risk on blueberries through innovative washing technologies. Food Control. 2013. 32: 621-625.

Vaid R, Linton RH, Morgan MT. Comparison of inactivation of Listeria monocytogenes within a biofilm matrix using chlorine dioxide gas, aqueous chlorine dioxide and sodium hypochlorite treatments. Food Microbiology. 2010. 27: 979-984.

$\mathrm{Xu} \mathrm{W}, \mathrm{Wu} \mathrm{C}$. The impact of pulsed light on decontamination, quality, and bacterial attachment of fresh raspberries. Food Microbiology. 2016. 57: 135-143.

https://doi.org/10.15616/BSL.2017.23.4.333

Cite this article as: KB Cho. Detection of Microbial Contamination in Commercial Berries. Biomedical Science Letters. 2017. 23: 333-338. 